\author{
Kinga Karpińska \\ University of Bialystok \\ e-mail: k.karpinska@uwb.edu.pl \\ ORCID: 0000-0002-3150-8339
}

\title{
SITUATION OF THE R\&D SECTOR IN POLAND IN THE FACE OF THE CURRENT CRISIS
}

\begin{abstract}
How has the current crisis caused by the COVID-19 pandemic affected R\&D and innovation in Poland? Numerous international studies conducted after the Great Depression in 2008-2010 show a strong procyclicality of investments in R\&D and innovation in companies: investments rise during the economic upturn and fall sharply during the crisis. This procyclicality is driven within firms both by internal financial resources and by differences in market incentives to innovate. It seems likely that the COVID-19 crisis caused financial weakness for many actors, having the most significant impact on the willingness or ability of smaller firms to support R\&D and innovation. However, where firms are able to sustain these investments, evidence from the crisis a decade ago suggests that they will be more likely to survive, grow more strongly, and have higher profitability. Based on the analysis of the literature and macroeconomic data, this paper presents several recommendations that, if implemented by R\&D actors, could help increase the efficiency of operations, even in times of crisis.
\end{abstract}

Keywords: crisis, COVID-19, R\&D, innovation.

\section{COVID-19 pandemic crisis}

Pandemic COVID-19, also known as the coronavirus pandemic, is a global disease outbreak. The pandemic has caused global economic disruption, including the largest global recession since the Great Depression. It is a global crisis because the entire world is experiencing the negative effects associated with the pandemic. Countries dependent on tourism, travel, hospitality, and entertainment are experiencing particularly severe hardships. Emerging and developing markets face additional challenges from unprecedented reversals in capital flows as global risk appetite and currency pressures diminish, as well as coping with weaker health systems and more limited fiscal space to provide support. Moreover, some economies en- 
tered the crisis with slow growth or high debt levels (Roper, Turner, 2020, pp. 504-505).

The crisis resulting from the COVID-19 pandemic shares two important similarities with the Great Financial Crisis of 2008-2010. First, in both cases there were or are acute exogenous shocks rather than business cycle fluctuations. Second, in both cases, firms suffered from sharp liquidity squeezes - in the case of the financial crisis a decade ago, from a sharp reduction in the availability of commercial financing, and in the case of the COVID-19 crisis, from a sharp reduction in turnover. In both cases, financial stringency will force companies to make quick strategic decisions on areas of spending and potential savings (Roper, Turner, 2020, pp. 510-511).

The cessation of operations due to the COVID-19 pandemic had a tremendous impact on the financial position of companies, which deteriorated significantly overnight. Those entities that were not generating high financial surpluses lost liquidity very quickly. The onset of the crisis often means a reduction of financial resources for investment in enterprises. Longterm goals, which can be achieved by investing in research and development and developing innovative solutions, are put on the back burner. However, where companies are able to sustain these investments, evidence from the previous financial crisis of 2008-2010 suggests that they will have a better chance of survival, stronger growth and higher profitability. Innovative entities are less adversely affected by the economic crisis and have a higher rate of growth. High-tech enterprises are characterized by highly developed adaptation abilities, which are crucial in case of sudden market changes (Spescha, Woerter, 2019, pp. 324-330).

Numerous international studies show a strong pro-cyclicality of R\&D and innovation investment in firms, meaning that investment rises during economic upturns and falls sharply in times of crisis. This procyclicality is due both to a firm's internal financial resources and to differences in market incentives to innovate (Rhaiem, Amara, 2019, pp. 195-230).

According to OECD research, companies in Europe and the United States that invested heavily in R\&D relatively quickly improved their product sales (OECD, 2012, pp. 45-50). Similar conclusions are provided by research conducted by the Institute of Economics of the Polish Academy of Sciences (Instytut Nauk Ekonomicznych Polskiej Akademii Nauk, 2012, pp. 13-19).

This correlation is primarily due to the fact that innovation allows you to gain a competitive advantage. This applies not only to individual enterprises, but also to entire branches of the economy, regions or countries. Innovations, especially in times of crisis, become the driving force 
of the economy and an important factor of modernization. At the same time, they build the foundations for sustainable economic growth. Despite the crisis in 2008, most European countries noted an increase in the innovative potential of their economies. One of the key success factors was a smoothly functioning system of links between the government, the scientific community and various sectors of industry. Pro-innovative countries also gave companies access to various sources of innovation financing, including public funds, tax breaks, loans, credit guarantees and offered support for micro and small enterprises (López-García, Montero Moral-Benito, 2013, pp. 625-636).

Arguably, the effects of a pandemic will not be the same for all firms. Evidence in the aftermath of the Great Depression of 2008-2010 suggests that firms that entered the COVID-19 crisis with greater cash reserves may also emerge stronger from the crisis because tightening credit constraints during the crisis allowed these firms to gain a strategic advantage over financially constrained competitors. Continuing to invest during the crisis allowed companies to gain a competitive advantage that also persisted during the recovery. Having financial reserves at the onset of a crisis gives companies a significant advantage in both the short and long term (Joseph, Kneer, van Horen, 2020, pp. 13-18).

Moreover, once the crisis has abated, firms with more financial backing may be able to undertake different types of innovation (more radical and risky) than more financially constrained firms (Latham, Braun, 2008, pp. 40-47). Entities with higher financial backing are more likely to engage in collaborative research activities that drive radical innovation, while firms with low financial backing are more likely to engage in short-term support and problem-solving activities that tend to lead to incremental innovation (La Rocca, Staglianò, 2019, pp. 1056-1068 oraz Bruneel, D'Este, Salter, 2016, pp. 696-700).

Based on the post-crisis research conducted between 2008 and 2010, it has also been observed that companies that are able to sustain their research activities gain a significant advantage when the post-crisis recovery emerges. This is because those that continue to invest in R\&D and innovation during the crisis tend to focus their efforts on: increasing productivity; better adapting to the changing needs and demands of suppliers, consumers and other stakeholders; and increasing organizational resilience (Flammer, Ioannou, 2015, pp. 13-17). In addition, the experience of innovation during recessionary periods strengthens a company's ability to invest in $\mathrm{R} \& \mathrm{D}$ during a new crisis (Amore, 2015, pp. 1574-1583). 
Although it is not known what the post-pandemic world will look like, based on the analysis of the current situation, it is possible to outline the most likely economic phenomena that will shape the new reality. They may occur simultaneously or one of them will become the most dominant. Although nothing can be certain, the current situation already shows that companies are facing accelerated digital transformation and the need to invest in innovative solutions.

\section{Situation of the R\&D sector in Poland before the outbreak of the pandemic}

Interest in $\mathrm{R} \& \mathrm{D}$, and more broadly in innovation activity, is motivated by its importance, which is expressed in many dimensions. In particular, it is noted that innovation drives economic growth, increases employment and income, contributes to the quality of life and competitiveness of nations (Atkinson, Ezell, 2014, p. 130). Innovation activities have a measurable impact on the performance of firms. In this context, it is argued, among other things, that innovation has a positive impact on the probability of survival of firms (Cefis, Marsili, 2006, p. 63), R\&D intensity significantly increases the future profitability of companies (Grabińska, Grabiński, 2018, pp. 58-59), and firms engaged in R\&D have higher productivity growth than non-innovative firms (Medda, Piga, 2014, pp. 428-429).

The primary measure of $R \& D$ expenditures is gross domestic $R \& D$ expenditures, which is the amount of total domestic $R \& D$ expenditures that are performed in the territory of a country in the indicated reporting period (Podręcznik Frascati, 2006, p. 416).

In 2010-2019, gross domestic outlays on R\&D in Poland increased more than 2.5 times - from PLN 10.4 billion to PLN 28.5 billion, as shown in Figure 1 . With the exception of 2016, when a decrease in domestic outlays on $\mathrm{R} \& \mathrm{D}$ was recorded relative to the previous year $(-0.7 \%)$, in all analyzed years their value increased year-on-year. 2018 turned out to be a record year in this respect, bringing an increase of the outlays in question by almost $1 / 4$ compared to the previous year, which was dictated primarily by a significant increase in internal outlays on $R \& D$ activity in the enterprise sector - an increase of PLN 3.7 billion; or $27.7 \%$. At the same time, outlays on $\mathrm{R} \& \mathrm{D}$ activity in the higher education sector increased by $20.1 \%$, the government sector - by $6 \%$, whereas private non-commercial institutions - by $7.4 \%$ (https://bdl.stat.gov.pl). 
Figure 1. Gross domestic expenditure on R\&D in PLN million and its dynamics (previous year $=100$ ) in 2010-2019

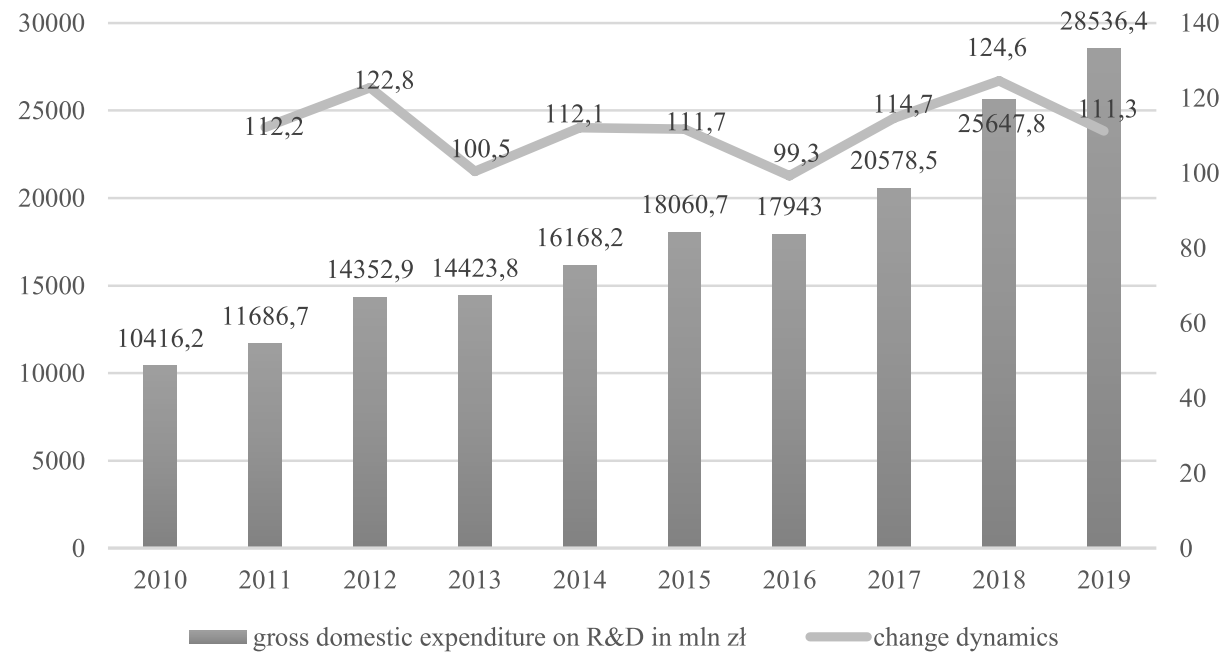

Source: based on CSO Local Data Bank, https://bdl.stat.gov.pl [accessed 28.06.2021].

Figure 2. Gross domestic expenditures on R\&D per capita in PLN and their dynamics (previous year $=100$ ) in $2010-2019$

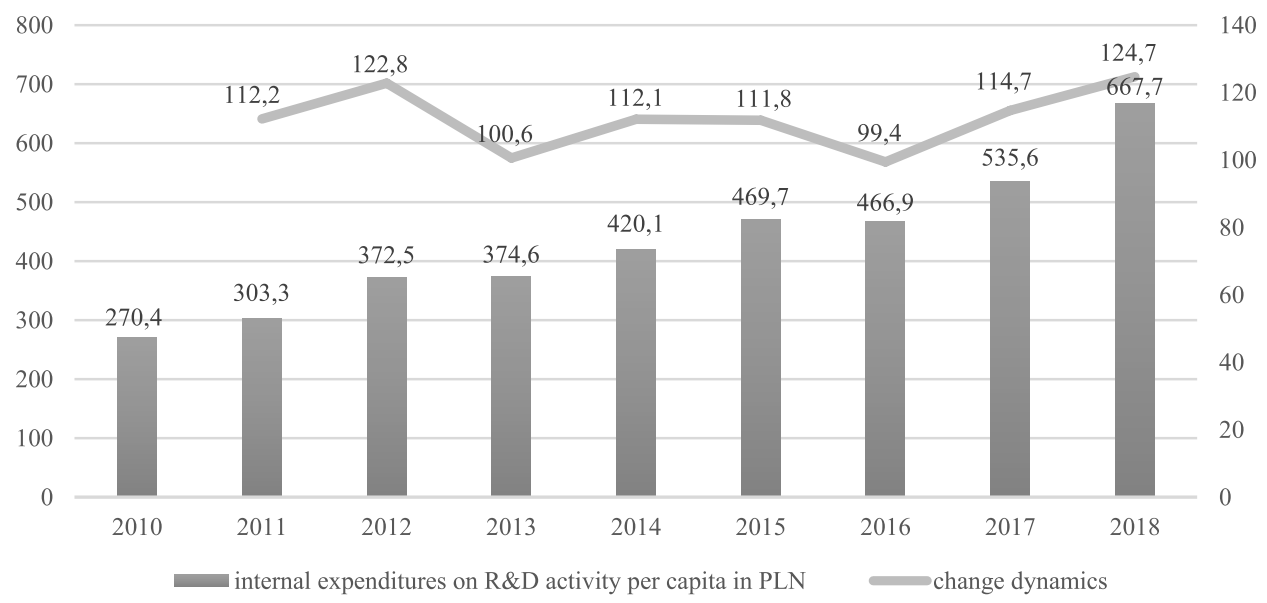

Source: based on CSO Local Data Bank, https://bdl.stat.gov.pl [accessed 28.06.2021].

As a consequence of the increase in gross domestic outlays on $R \& D$ activity, their value per capita also increased - from PLN 270.4 in 2010 to PLN 698.4 in 2019. Due to the low dynamics of changes in the number of inhabitants in Poland, the dynamics of internal outlays on R\&D activity per capita followed a similar pattern as in the case of the value of gross domestic outlays on R\&D activity (Figure 2). 
Significant role in the analysis of R\&D activity is played by the breakdown of internal expenditures by executive sectors, i.e. groups of entities in which scientific research or development works are conducted, which include: the sector of enterprises, government, higher education and private non-commercial institutions. The analysis of data from 2010-2019 according to this cross-section allows us to notice considerable changes in the structure of internal expenditures on R\&D in Poland (Table 1).

Table 1

Structure of internal R\&D expenditures by executive sector in 2010-2019

\begin{tabular}{|l|r|r|r|r|r|r|r|r|r|r|}
\hline Years & 2010 & 2011 & 2012 & 2013 & 2014 & 2015 & 2016 & 2017 & 2018 & 2019 \\
\hline Sector & \multicolumn{10}{|c|}{ Structure index } \\
\hline enterprises & 26,6 & 30,1 & 37,2 & 43,6 & 46,6 & 46,6 & 65,7 & 64,5 & 66,1 & 68,0 \\
\hline government & 35,9 & 34,5 & 28,0 & 26,8 & 24,0 & 24,4 & 2,5 & 2,3 & 1,9 & 2,5 \\
\hline higher education & 37,2 & 35,1 & 34,4 & 29,3 & 29,2 & 28,9 & 31,4 & 32,9 & 31,7 & 29,3 \\
\hline non-commercial institutions & 0,3 & 0,2 & 0,4 & 0,3 & 0,3 & 0,2 & 0,4 & 0,3 & 0,3 & 0,2 \\
\hline
\end{tabular}

Source: based on Eurostat, https://ec.europa.eu/eurostat/data/database [accessed 28.06. 2021].

In 2019, the enterprise sector accounted for the largest share of total internal outlays on $\mathrm{R} \& \mathrm{D}$, which was 2.5 times the value recorded in 2010 . As a result of high growth dynamics of internal expenditures of the enterprise sector on $\mathrm{R} \& \mathrm{D}$, at the end of the period under consideration its share in total expenditures reached $68 \%$ compared to $26.6 \%$ in 2010 . The observed changes in the structure of expenditures on $R \& D$, manifested by an increase in the share of expenditures of the enterprise sector, are a desirable phenomenon. The literature emphasizes that it is $R \& D$ expenditures incurred by enterprises that are particularly important for the development of the economy, as they usually guarantee a faster commercialization of research results (Grzelak, Laskowska, Roszko-Wójtowicz, 2018, p. 13).

The successive increase in the share of the business sector in internal $R \& D$ expenditures was accompanied by a gradual decline in the share of the government sector - a reduction from $35.9 \%$ in 2010 to $2.5 \%$ in 2019 . With respect to the higher education sector, in 2019, nearly one in three zlotys of total internal R\&D expenditures in Poland was its share. The last of the performing sectors, the private non-commercial institutions sector, had a marginal share in the total considered outlays, not exceeding $0.4 \%$ in the period under review. 
In the context of the increase in $\mathrm{R} \& \mathrm{D}$ spending in the corporate sector, it is worth mentioning the changes to the $\mathrm{R} \& \mathrm{D}$ tax credit that came into effect on January 1, 2018. (KPMG, 2019, pp. 6). Since the beginning of 2018, the so-called Big Law on Innovation has been in force, which significantly changed the shape of the relief. When accounting for the 2018 tax year, all companies conducting R\&D activities can write off $100 \%$ of the costs eligible for the relief (it was $50 \%$ or $30 \%$ depending on the type of cost), and units with the status of a research and development center can write off even $150 \%$ of the costs. According to a study published by KPMG, clarification of the relief's regulations and clearer requirements, as well as increased financial benefits, were key factors that prompted those who did not take advantage of the relief in 2017 to take advantage of it in 2018. According to the above study, $43 \%$ of surveyed companies with such activities took advantage of the R\&D relief in 2018 - three times as many as in the previous year (KPMG, 2019, pp. 6-7). Increased interest in using the R\&D tax credit in 2018 is also signalled by data from the Ministry of Development, Labour and Technology. They show that in the 2018 tax return 951 CIT taxpayers took advantage of the R\&D relief (60\% more than the year before), who deducted PLN 1.7 billion from their tax base, in 2019, 1342 CIT entities have already benefited - a $41 \%$ increase from the previous year and 1195 PIT entities - a 34\% increase from the previous year (MRPiT, 2019, p. 1). Despite the favorable changes made to the $R \& D$ tax credit, it is still underutilized by $R \& D$ entities. Of the companies that have heard about the R\&D tax relief, $48 \%$ have used this mechanism. For almost half, it was a one-time experience, and less than one in three entities settled the relief twice. Taking into account the size of enterprises, it was mainly large entities (with more than $250 \mathrm{em}$ ployees) that used this tax preference at least once. In case of the smallest companies only one in three settled the R\&D tax allowance (Burzyńska, 2021, pp. 18).

In Poland, most companies finance innovations on the basis of their own resources from a separate $R \& D$ budget. In turn, forms of external financing are much less frequent. According to Ayming's "Road to Innovation" report, it is primarily EU grants that are used as external funding for R\&D activities $-49 \%$ of surveyed companies applied for them in 2019 . The R\&D tax credit was used by $43 \%$ of respondents, while loans and credits were used by $23 \%$. According to the respondents, in order to increase the use of external funding, steps would need to be taken, i.e. (Burzyńska, 2020, pp. 10-11):

- R\&D tax relief - higher level of relief (67\%) - taking advantage of R\&D tax relief is risky as the rules are often unclear and complicated, for ex- 
ample, problems with accounting for the depreciation of fixed assets that are the result of research and development, or accounting for the cost of technical consulting;

- easier access to grants (65\%) - many entrepreneurs (especially those starting their R\&D activity) do not know where to look for information on grants for research and development and how to apply for them;

- less formal procedures (57\%) - many entrepreneurs do not decide to use external financing because most of these instruments are associated with excessive bureaucracy and procedures that are often unclear and time-consuming.

Financing R\&D activities mostly with own funds is very risky, especially when the world is in crisis. Due to the outbreak of the COVID-19 pandemic, many entrepreneurs were forced to revise their plans and minimize spending on R\&D. Before the pandemic, most entities planned to increase their $R \& D$ budgets over the next three years. In the current situation, a large percentage of research entities limit this type of spending, due to cost-cutting in other areas of business activity, although in full awareness that the resulting innovations (the effect of R\&D activity) could contribute to faster growth in subsequent periods. Therefore, reaching for external financing may turn out to be not only an additional factor intensifying innovative activity in a company, but in many cases, even a way to sustain R\&D activity in the times of the economic slowdown (PFR, 2021, p. 1).

The essence and measure of the effectiveness of the R\&D sector is primarily the implementation aspect of the conducted research. In Poland most companies rely on their own know-how resources, omitting cooperation with scientists. On the international arena, on the other hand, the situation is reversed. Leading enterprises in terms of innovation closely cooperate with scientific centers. Why then do Polish entities so rarely decide on such cooperation? In the opinion of entrepreneurs, building effective relations between universities and business is hindered first of all by time-consuming and complicated formalities on the part of the scientific unit (extended decisionmaking process, multiple units of the university involved in the activity, difficulty in agreeing on the terms of cooperation). Some legal restrictions are also a barrier (e.g. the company is not able to use part of the infrastructure of the scientific unit purchased from EU funds or the necessity to establish with the authorities of the faculty the possibility and scope of cooperation with a given scientist). The situation is not facilitated by complicated and time-consuming processes of applying for external funds and accounting for them. Entrepreneurs also point to the high costs of conducting $R \& D$ works, which exceed the capabilities of their own business entities, 
and external funding represents only a certain percentage of total costs. Solutions proposed by scientists are not always characterized by a high level of readiness for implementation - although scientifically perfect, they are often impractical and detached from market reality. The reason for this, in the opinion of entrepreneurs, may be insufficient experience of scientists in industrial work and the divergence of scientific and implementation objectives, not conducive to combining the duties in the scientific institution and the company. In turn, the main barriers from the perspective of the scientist are inscribed in the system of evaluation of scientific career, built on strictly scientific activities. The time of scientists is also occupied by teaching duties. Internship in industry is not an obligatory element of a research career (Wycisk, Płaszczyca, Gajda, 2018, pp. 33-34).

It is also a characteristic feature of Polish R\&D enterprises that they do not have an innovation strategy. Only less than $30 \%$ of such entities have a defined strategy and usually these are large enterprises or those which have been engaged in R\&D activity for many years. On the other hand, smaller organisations that have just started their research activity have never developed such a strategy (Burzyńska, 2020, p. 10). Unfortunately, this is a weakness of Polish research entities, because the ability of the body, which lies in the hands of top management. This is due to the fact that innovation concerns virtually every function in the organization, which requires designing a complex system to support it. Such a system consists of, among other things, structure, processes, talent management and how ideas are selected for implementation. The company's strategy and organizational culture are important, because it depends on them whether the company is innovative.

\section{The impact of COVID-19 pandemic on R\&D sector activities - recommendations}

It is natural that during the economic crisis there is a phenomenon of accumulation of technology and innovation, which in the initial stage of this process provides a new stimulus to the development of the economy and creates an opportunity to break the bad economic situation and often leads to consolidation and concentration of industry, and thus to the creation of various cooperative forms in the form of, for example, clusters. The problems faced by the economy during and after the crisis can often be a catalyst for the emergence of completely new technologies, or even influence the development of a new sector through the recombination of already 
existing knowledge and technology and the adaptation of existing technological solutions in a new context. Although this type of innovation does not represent something entirely new, it opens up new markets and applications for existing technologies and sets new paths for technological development (Kowalski, 2011, pp. 32-33).

Based on the analysis of the literature on the subject and macroeconomic data, this paper formulates conclusions and recommendations that can be a signpost for entrepreneurs who appreciate the importance of innovation and want to develop it, even in times of global crisis.

\section{Increasing the role of external funding for innovation}

The key barriers to developing innovation in companies are high costs and lack of sufficient funding. Before the coronavirus pandemic, most of the surveyed entities planned to increase their R\&D budgets over the next three years. Unfortunately, due to the COVID-19 crisis, many entrepreneurs were forced to revise their plans and minimize spending. In this situation reaching for external financing may turn out to be not only an additional factor intensifying innovative activity in a company, but in many cases even a way to sustain R\&D activity in times of economic slowdown. However, the above analyses show that enterprises in Poland do not use the potential of external financing.

The most accessible solution for companies is the research and development relief, which allows CIT and PIT taxpayers to deduct $100 \%$ of qualified costs. For example, with PLN 2 million of qualified expenses, a tax liability can be reduced by PLN 380 thousand (19\% CIT rate). Research and development works that have not been successfully completed are also eligible for the relief. It can be settled up to five years back.

However, it needs further promotion among entrepreneurs, as it still remains an unfamiliar mechanism for many of them. Only half of the entities conducting R\&D activity know about this preference, and another half of them have used it at least once. The SME sector is the least likely to take advantage of the $R \& D$ tax relief, and it is in this sector that additional financial means would be most useful. The introduction of the R\&D tax allowance was an important step towards increasing the innovativeness of companies in Poland. The point is to minimize formalities or to unify the line of interpretation of tax regulations, so that taxpayers could settle the relief safely and without unnecessary difficulties. A very good solution would also be to increase the deductible costs for all entrepreneurs. Some taxpayers are interested in taking advantage of the research and development relief, but its amount in relation to the amount of work to be incurred is still too 
small. Perhaps the proposed change in 2022 , i.e., the ability to deduct $200 \%$ of eligible costs, will increase the use of this credit by businesses. For some companies/industries, it is also worth looking at the new planned reliefs to be introduced in 2022, i.e.: robotisation relief (50\%), innovative worker relief $(100 \%)$ and prototype relief $(30 \%)$.

Another source of support for R\&D activities are EU subsidies. They are granted in a competition for companies and consortia to develop and validate new products or processes that will be innovative on the scale of a given industry, region or country. They apply to projects that a company only plans to carry out. Such a project must be carried out according to a precisely described plan and within an approved budget, and its implementation assumes the achievement of previously assumed indicators. The reward for the selected companies is a grant of up to $80 \%$ of the costs, depending on the type of research and the size of the company. Compared to the $R \& D$ tax credit, applying for grants is a much more difficult activity, primarily because a rather complicated application is required. Moreover, the lengthy grant application process is discouraging. Therefore, more transparency is needed to encourage further use of the grant.

The newest instrument is the IP Box relief introduced in 2019. It is a preferential $5 \%$ income tax rate for taxpayers who obtain income thanks to the results of their own $\mathrm{R} \& \mathrm{D}$ works, which have the form of, among others, a patent, utility model, industrial design or copyright to a computer program. Unfortunately, there are still very few entrepreneurs who even know that this type of solution exists.

Undoubtedly, Polish entrepreneurs expect government support in introducing innovations, and certainly an extended array of tax incentives will prove helpful in rebuilding innovation activity after the Covid-19 crisis and in stimulating it further. What is important is that the ratio of possible benefits from pro-innovation allowances is proportional to the commitment involved in preparing for their application. Transparency of tax rules is also important. As part of the expansion of tax incentives, it is worth considering standardizing the amount of deductions for each of the reliefs and equalizing the time period in which costs that have not been deducted can be accounted for in the future due to the amount of tax due.

\section{Developing an innovation strategy}

As it turns out, only a small proportion of companies develop and implement an innovation strategy that aligns innovation activities with the company's business strategy. An innovation strategy should create a bridge between the mission and vision and the day-to-day activities of the team to 
deliver the desired results. The strategy indicates how solutions are sought within the organization, how ideas are transformed into business models and product or service concepts, and what determines funding for further project development. Such an approach makes innovation seen in the organization as a continuous process, rather than a one-time reaction in response to the actions of competitors or the need to suddenly adapt to the market. At the same time, the lack of an innovation strategy often causes different functions in the organization to pursue conflicting priorities.

If the fundamental element of the strategy is to rely on innovation, then one should not talk about innovation strategy, but about innovation that supports the strategy and development of the company. In addition, an innovation strategy is not just a guidance document on innovation. Most companies that are considered innovative never had such a strategy when they were created, but they had ideas, passion and determination. What is often forgotten is the need to develop an innovation culture, people competence, process improvement and project work methods. More important than creating an innovation strategy document is building a climate in the company that will motivate people to seek innovations that support the strategy.

In the period of market turbulence, the enterprise innovation strategy is subject to verification. Entities that want to actively respond to technological challenges and crises caused by external factors, such as COVID-19, in addition to the capital base must have resources in the form of intellectual capital and an appropriate model for managing this capital. Properly defined in the innovation strategy, a portfolio of breakthrough ventures, correlated with the long-term development plan of the company, can facilitate overcoming the economic effects of coronavirus.

\section{Creating a culture of innovation}

Creating an innovative culture in a company requires the formation of such a work environment in which there is openness, mutual trust, orientation to the acquisition of new knowledge and encouragement to take their own initiative. The organization which manifests the features of innovative culture, to a greater extent undertakes and develops innovative activities within it. Meanwhile, companies in Poland have a long way to go in the innovation revolution, which has implications for their international position. This is partly due to the fact that the innovative culture in Polish companies is relatively underdeveloped. Creating an innovative culture in a company requires changes in the way of thinking about introducing innovations and systemic changes in the organization itself. In a company with an innovative 
culture, creative attitudes are promoted, employees' initiatives are appreciated and changes and innovations are introduced. It is popular to create special cells that act as a catalyst for innovation.

The pandemic has shown how important, in a period of uncertainty and volatility, is an innovative culture understood not only as the creation of new products and services, but also as rapid adaptation to change and courage to act. Entities which have not yet developed such a culture may find it more difficult to go through the current crisis, and also less effective in implementing the innovations they have developed.

\section{Intensification of cooperation between enterprises and scientific units}

The potential of such cooperation is not fully exploited and does not always proceed in a certain way. This often results from the divergence of goals between science and business. For scientists, the main measure of success is scientific publications, while for business - industrial implementations. Entrepreneurs primarily focus on the practicality of the proposed solutions, cost reduction and rapid implementation time. Scientists, on the other hand, often focus on other scientifically important objectives, which are no longer so important from a business perspective. In addition, the proposals of scientists are often of too high quality, corresponding to the highest scientific standards. As a result, they are too expensive, sometimes impractical or difficult to implement and disconnected from market reality. According to entrepreneurs, this results from the lack of experience of scientists in industry and knowledge of the market to understand the needs and realities of business operations.

It should be emphasized, however, that companies that have cooperated with the scientific and research sector value such partnerships due to the significant substantive contribution to their own activities. Such cooperation contributes to the development of personnel in their own enterprise. The combination of knowledge of company employees about the market and customer needs with the expertise of scientists allows to solve complex problems and create innovative solutions that would not be possible to develop independently by either party.

\section{Investing in staff and own know-how}

Among the key elements that build the innovativeness of the company is the expertise of qualified employees. Investing in the potential of its own staff helps to develop the know-how of the organization and at the same time influences the more effective use of the internal R\&D infrastructure. Despite 
the difficulties and challenges connected with the realisation of research and development works inside a company, the benefits can exceed the incurred expenses. First of all, the company gains full control over the research and development process and can make ongoing modifications as needed. Last but not least, when developing innovative solutions in-house, key knowhow is better protected and there is less risk that important information may leak out.

Separation of a separate $R \& D$ unit facilitates effective management of innovation work and allocation of resources in response to current demand. In addition, it enables the introduction of procedures and tools that make it possible to share knowledge among employees and archive it in a fixed way, so that it can serve the entire company in the future.

\section{Conclusions}

The coronavirus pandemic is a crisis not only in financial terms, but also in social and health terms. Today, a huge responsibility lies on the shoulders of business owners, who must act in this difficult time to maintain liquidity and preserve jobs. Based on the literature and the experience of the crisis a decade ago, it can be concluded that success will largely depend on the company's flexible adaptation to market changes, and in this innovation can play a key role.

Economic downturns stimulate economic change by forcing necessary adjustments and stimulating the search for new ways to increase the efficiency of the activities undertaken. $\mathrm{R} \& \mathrm{D}$ and innovation can therefore be a factor in accelerating recovery from crisis.

The coronavirus pandemic is causing many companies to cut back on R\&D investments. Meanwhile, it is those companies that implemented innovative solutions before the crisis that fare much better in a difficult economic situation.

The crisis caused by the COVID-19 pandemic can be a catalyst for innovation in many sectors, both modern and traditional. It can also spur innovation in the way work is organized at the level of firms and individuals, and in the way production is (re)organized locally and globally. Unlocking the above potential is now essential, but this also requires an increased commitment of external funding.

The article, based on the analysis of literature and macroeconomic data, also presents some recommendations, the implementation of which by the entities of the R\&D sector could contribute to increasing the effectiveness of 
activities, even in times of crisis. Undoubtedly, the most important of these is to increase the use of external funding for innovation or self-financing in the form of the use of tax credits.

\section{R E F E R E N C E S}

Amore M., 2015, Companies learning to innovate in recessions, "Research Policy" 44 (8), DOI: 10.1016/j.respol.2015.05.006.

Atkinson R.D., Ezell S.J., 2014, Innovation Economics: The Race for Global Advantage, Yale University Press, New Haven.

Bank Danych Lokalnych, https://bdl.stat.gov.pl [access: 28.06.2021].

Bruneel J., D'Este P., Salter A., 2016, The impact of financial slack on explorative and exploitative knowledge sourcing from universities: Evidence from the UK, "Industrial and Corporate Change" 25 (4), DOI: 10.1093/icc/dtv045.

Burzyńska M., 2021, Biznes oddychający z ulgą. 5 lat ulgi B+R w Polsce, https:// www.ayming.pl/analizy-i-aktualnosci/raporty/biznes-oddychajacy-z-ulga-5lat-ulgi-br-w-polsce/ [access: 29.06.2021].

Burzyńska M., 2020, Droga do innowacji a COVID-19, https://www.pipc.org.pl/ files/1555078737/file/Droga_do_innowacji._Wyzwania_CEO._Raport_Ayming _2020.pdf [access: 29.06.2021].

Cefis E., Marsili O., 2006, Survivor: The Role of Innovation in Firms' Survival, "Research Policy", 35 (5), DOI: 10.1016/j.respol.2006.02.00.

Czy pandemia wpłynęła na środki na innowacje? Ponad 1/3 europejskich firm zmniejszyła wydatki, 2021, PFR, https://startup.pfr.pl/pl/aktualnosci/czypandemia-wplynela-na-srodki-na-innowacje-ponad-13-europejski/ [access: 03.07.2021]

Eurostat, https://ec.europa.eu/eurostat/data/database [access: 28.06.2021].

Flammer C., Ioannou I., 2015, The dog that didn't bark: Long-term strategies in times of recession, London Business School, London, DOI: 10.2139/SSRN.26 21247.

Grzelak M.M., Laskowska I., Roszko-Wójtowicz E., 2018, The Importance of Research and Development Expenditure for the Competitiveness of Manufacturing Enterprises in Poland. The Application of Panel Models, "Ekonometria", 22 (3), DOI: 10.15611/eada.2018.3.01.

Joseph A., Kneer C., van Horen N., 2020, All you need is cash: Corporate cash holdings and investment after the financial crisis, Bank of England Staff Working Paper (843), Bank of England, London.

Kowalski A.M., 2011, Wpływ kryzysu gospodarczego na procesy współpracy i konkurencji, "Master of Business Administration" 2 (112).

La Rocca M., Staglianò R., La Rocca T., 2019, Cash holdings and SME performance in Europe: The role of firm-specific and macroeconomic moderators, "Small Business Economics" (53), DOI: 10.1007/s11187-018-0100-y. 
Latham S.F., Braun M.R., 2008, The performance implications of financial slack during economic reces-sion and recovery: Observations from the software industry, "Journal of Managerial Issues" 20 (1).

López-García P, Montero J.M. Moral-Benito E., 2013, Business cycles and investment in productivity enhancing activities: Evidence from Spanish firms, "Industry and Innovation" 20 (7), DOI: 10.1080/13662716.2013.849456.

Medda G., Piga C., 2014, Technological Spillovers and Productivity in Italian Manufacturing Firms, "Journal of Productivity Analysis", 41 (3), DOI: 10.1007/s11123-013-0351-1.

Podręcznik Frascati. 2006, Proponowane procedury standardowe dla badań statystycznych w zakresie działalności badawczo-rozwojowej, wydanie szóste, MNiSW, Warszawa.

Przedsiębiorcy coraz chętniej sięgają po ulgę B+R, 2019, Ministerstwo Rozwoju, Pracy i Technologii, https://www.gov.pl/web/rozwoj-praca-technologia/ przedsiebiorcy-coraz-chetniej-siegaja-po-ulge-br [access: 04.07.2021].

Raport o innowacyjności gospodarki Polski 2008-2012, 2012, Instytut Nauk Ekonomicznych Polskiej Akademii Nauk, http://inepan.pl/publikacje-sieci-msnraporty-o-innowacyjnosci/ [access: 01.07.2021].

Rhaiem K., Amara N., 2019, Learning from innovation failures: A systematic review of the literature and research agenda, "Review of Managerial Science", https://link.springer.com/article/10.1007/s11846-019-00339-2, DOI: 10.1007/ s11846-019-00339-2.

Roper S., Turner J., 2020, R\&D and innovation after COVID-19: What can we expect? A review of prior research and data trends after the great financial crisis, "International Small Business Journal: Researching Entrepreneurship", 38 (6), DOI: $10.1177 / 0266242620947946$.

Spescha A. Woerter M., 2019, Innovation and firm growth over the business cycle, "Industry and Innovation", 26 (3), DOI: 10.1080/13662716.2018.1431523.

Technology and Industry Outlook 2012, OECD, https://read.oecd-ilibrary.org/ science-and-technology/oecd-science-technology-and-industry-outlook-2012_ sti_outlook-2012-en\#page45 [access: 22.06.2021].

Ulga podatkowa na badania i rozwój, grudzień 2019, KPMG, https://assets.kpmg/ content/dam/kpmg/pl/pdf/2019/12/pl-raport-kpmg-pt-ulga-podatkowa-nabadania-i-rozwoj.pdf [access: 02.07.2021].

Wycisk A., Płaszczyca M., Gajda M., 2018, Skuteczna współpraca nauka-biznes w opinii przedsiębiorców, Politechnika Warszawska, Warszawa. 